\title{
Short communication: Identification of Corynebacterium bovis by MALDI-mass spectrometry
}

\author{
Helio Langoni, ${ }^{* 1}$ Carolina Polo Camargo da Silva, ${ }^{*}$ Marcella Zampoli Troncarelli, $\dagger$ Alessandra Tata, $\ddagger$ \\ Katia Roberta Anacleto Belaz, $\ddagger$ Marcos Nogueira Eberlin,‡ Samea Fernandes Joaquim, ${ }^{*}$ \\ Felipe Freitas Guimarães, ${ }^{*}$ Renata Bonini Pardo,§ and Eduardo Nardini Gomes\# \\ *Departamento de Higiene Veterinária e Saúde Pública, Faculdade de Medicina Veterinária e Zootecnia, Universidade Estadual Paulista, \\ Campus de Botucatu, Distrito de Rubião Júnior s/n, Botucatu, SP 18618-970, Brazil \\ †Instituto Federal Catarinense, Rodovia SC-283 Km 08 Fragosos, Concórdia, SC 89703720, Brazil \\ fThomson Mass Spectrometry Laboratory, Institute of Chemistry, University of Campinas, Campinas, SP 13083-859, Brazil

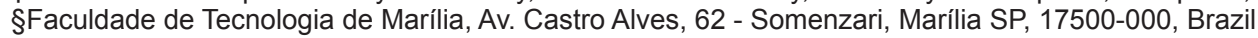 \\ \#Departamento de Engenharia Agronômica e Engenharia de Pesca, Universidade Estadual Paulista, Campus de Registro, \\ Avenida Nelson Brihi Badur, 430 - Vila Tupy, Registro SP, 11900-000, Brazil
}

\begin{abstract}
Corynebacterium bovis is a mastitis-causing microorganism responsible for economic losses related to decrease in milk production. The aim of the study was identify Corynebacterium spp. strains recovered from milk samples of subclinical mastitis by using matrixassisted laser desorption/ionization mass spectrometry (MALDI-MS). Samples were collected during a 10-mo mastitis-monitoring program in a high-production dairy farm. In this study, 80 strains were analyzed; from these $54(67.5 \%)$ were identified at species level as Corynebacterium bovis, $24(31.2 \%)$ isolates were identified at the genus level as Corynebacterium spp., and only $1(1.35 \%)$ isolated had unreliable identification. Results demonstrated that MALDI-MS could be an important technique for the identification of Corynebacterium spp. in milk.
\end{abstract}

Key words: mastitis, Corynebacterium bovis, proteomic characterization

\section{Short Communication}

Mastitis is an important cause of economic losses in dairy farms. This disease has great relevance to public health mainly by direct transmission of food-borne pathogens or due to the ingestion of their produced toxins and enterotoxins (de Freitas Guimarães et al., 2013; Langoni, 2013).

The most frequent etiological agents of bovine mastitis are Staphylococcus aureus, CNS, Streptococcus agalactiae, Streptococcus dysgalactiae, Streptococcus

Received August 25, 2016.

Accepted January 6, 2017.

${ }^{1}$ Corresponding author: hlangoni@fmvz.unesp.br uberis, Escherichia coli, and Corynebacterium bovis. The latter is the most common among Corynebacterium spp. involved in bovine IMI (Watts et al., 2001). Whereas many authors consider C. bovis either a normal inhabitant of the teat canal or a minor pathogen of bovine mastitis (Pankey et al., 1985; Ngatia et al., 1991; Bexiga et al., 2011), other studies described this organism as an important causative agent of mastitis cases (Costa et al., 1985; Haltia et al., 2006; Schukken et al., 2009; Langoni et al., 2016) with significant deteriorating effects on milk production (Domingues et al., 1998, Gonçalves et al., 2016).

Studying mammary glands naturally infected by C. bovis, Victória et al. (2005) observed median SCC equal to $262 \times 10^{3}$ and $806 \times 10^{3}$ cells $/ \mathrm{mL}$ in milk samples negative and positive to C. bovis, respectively, with some samples as high as $1 \times 10^{6}$ cells $/ \mathrm{mL}$. Currently available techniques used for Corynebacterium spp. identification are laborious biochemical schemes or molecular diagnosis, requiring the use of many reagents and specific primers (besides previous standardization), specialized laboratories, and professional expertise (Bexiga et al., 2011).

The matrix-assisted laser desorption/ionization mass spectrometry (MALDI-MS) technique permits rapid, precise, and species-specific diagnosis for identification of mastitis pathogens (Gonçalves et al., 2014; Tomazi et al., 2014). Considering the relevance of $C$. bovis as an etiological agent on bovine mastitis, the objective of the present study was to identify Corynebacterium spp. strains recovered from milk samples of subclinical mastitis by MALDI-MS.

The criterion adopted for selection was the isolation of Corynebacterium spp. during a 10-mo, monthly sample strategy of all lactating cows in a large highproduction dairy farm. A total of 244 Holstein cows 
were evaluated. The entire herd of lactating cows was screened using a strip cup and the California mastitis test (Schalm and Noorlander, 1957). Mammary quarters positive by strip cup test or California mastitis test score 1 to 3 were aseptically sampled and milk samples were stored in refrigerated isothermal boxes for transport to the laboratory for bacteriological analysis (NMC, 1999).

In the laboratory, $10 \mu \mathrm{L}$ of each sample was streaked both on $8 \%$ sheep blood agar and on MacConkey agar (Oxoid Ltd., Basingstoke, UK) plates. The inoculated plates were incubated, aerobically, at $37^{\circ} \mathrm{C}$ during 3 d, with growth observation every $24 \mathrm{~h}$ (NMC, 1999). Corynebacterium spp.-suspected colonies were morphologically characterized by Gram stain, phenotypically classified according to biochemical tests suggested by Krieg and Holt (1994), and then inoculated in brain and heart infusion for proteomic analysis

Pleomorphic gram-positive isolates with characteristics of Corynebacterium spp. were cryopreserved (1:1) by adding $500 \mu \mathrm{L}$ of Tween 80 (Vetec, Rio de Janeiro, Brazil) enriched brain and heart infusion containing microorganisms in $500 \mu \mathrm{L}$ of $40 \%$ sterile glycerol in sterile $1.5-\mathrm{mL}$ cryogenic tubes, kept frozen at $-20^{\circ} \mathrm{C}$ until characterization was performed by MALDI-MS (Barreiro et al., 2010; Gonçalves et al., 2014; Tomazi et al., 2014).

Samples were thawed and individually plated by streaking on $8 \%$ sheep blood agar and then incubated under $37^{\circ} \mathrm{C}$ for $48 \mathrm{~h}$. For MALDI-MS, colonies were transferred to sterile microtubes filled with $300 \mu \mathrm{L}$ of deionized water, homogenized, and $900 \mu \mathrm{L}$ of ethanol (HPLC) was added for bacterial inactivation.

Microtubes were centrifuged at 1,500 $\times g$ for 3 min at room temperature and the supernatant was discarded inverting the tubes. After another centrifugation, the remaining ethanol was removed. For bacterial lysis, after drying for $30 \mathrm{~min}$ at room temperature, a $70 \%$ formic acid solution was mixed at a sufficient volume to cover the pellet (approximately $30 \mu \mathrm{L}$ ). The content was homogenized in a shaker for 2 min until the whole pellet was completely undone. We then added $30 \mu \mathrm{L}$ of $100 \%$ acetonitrile, homogenized the mixture in a tube shaker, and centrifuged at 14,000 $\times g$ for $3 \mathrm{~min}$ at room temperature to separate proteins from bacterial cells, specifically the ribosomal prtoeins (Fenselau and Demirev, 2001) from which MALDI-MS spectrums were obtained and used to identify the agent.

One microliter of this bacterial extract was placed onto a 384-well plate (Bruker Daltonics, Billerica, MA) and dried at room temperature. The dried bacterial extract was overlaid with $1.0 \mu \mathrm{L}$ of matrix solution composed of $\alpha$-cyano-4-hydroxy-cinnamic acid (CHCA) diluted in $50 \%$ acetonitrile and $2.5 \%$ trifluoroacetic acid.

The MALDI-MS analysis was performed in an Autoflex III (Bruker Daltonics, Bremen, Germany) MALDI time-of-flight mass spectrometer operated in the linear mode and equipped with a $337-\mathrm{nm}$ smart beam laser using FlexControl 3.3 software (Bruker Daltonics). The bacterial test standard (Bruker Daltonics) was used for the mass calibration. The mass spectra were collected within the mass range of $m / z 2,000$ to 20,000 . The spectra were analyzed with the database library MALDI Biotyper 3.0 software (Bruker Daltonics). The algorithm used by MALDI Biotyper confronts the spectra of the unknown sample with pattern samples existing in a database (Lartigue et al., 2009).

Out of 1,813 milk samples submitted to microbiological culture, Corynebacterium spp. strains were isolated in $600(33 \%)$ at the beginning. Considering the 244 studied cows, $50(20.5 \%)$ were positive for Corynebacterium spp. in one or more teats; from these teats, the same pathogen was recurrently isolated at least once again in 23 (46\%), which were included in the study.

In relation to the persistence of this pathogen causing subclinical infection during the lactation, it was observed that in $43.48 \%(10 / 23)$ of these animals Corynebacterium spp. was recovered only twice, within a mean time equal to $111 \mathrm{~d}$ of subclinical infection. In $26.1 \%(6 / 23)$, there were 3 isolations, with an average of $190 \mathrm{~d}$ of subclinical infection; $30.43 \%$ (7/23) showed 4 or more isolations within a mean time of $197 \mathrm{~d}$ of infection.

According to the MALDI-MS technique, 54 (67.5\%) Corynebacterium spp. isolated were identified as Corynebacterium bovis (Table 1), reinforcing its involvement in mastitis epidemiology of the considered herd. This

Table 1. Identity of 80 isolates of Corynebacterium spp. according to the pattern Corynebacterium bovis, according to matrix-assisted laser desorption/time-of-flight mass spectrometry (MALDI-MS) technique

\begin{tabular}{lcl}
\hline Number of samples & Percentage & Identity with Corynebacterium bovis pattern \\
\hline 54 & 67.50 & High identity with pattern sample \\
25 & 31.25 & Probable identity with pattern sample \\
1 & 1.25 & Unidentified species \\
80 (total) & 100 & \\
\hline
\end{tabular}


supported the conclusions of Costa et al. (1985) and Haltia et al. (2006), who found this pathogen in subclinical and clinical mastitis cases.

The genus Corynebacterium includes over 85 species isolated from animals or humans beings (Funke and Bernard, 2011). Species identification of Corynebacterium is challenging, and clinical laboratories need better strategies for identification. Alatoom et al. (2012) studied 92 Corynebacterium spp. clinical isolates from human cases and concluded that MALDI is a useful approach for identification of this genus species; however, C. bovis was not included among these isolates. Gonçalves et al. (2014) analyzed 180 isolates presumptively classified as Corynebacterium spp. and verified that MALDI correctly identified $161(89.4 \%)$ of the Corynebacterium spp. isolates at species level.

According to the results of the present study, C. bovis were identified in $67.5 \%$ of all Corynebacterium spp. isolates; C. bovis was positively identified in $31.25 \%$ isolates. This demonstrates that MALDI-MS could be an important tool for the identification of these pathogens and confirms the importance of this pathogen as subclinical mastitis agent.

\section{ACKNOWLEDGMENTS}

This study was funded by FAPESP (The São Paulo State Official Foundation to Support Research; Grant number 2012/24213-0) with a grant to Carolina Polo Camargo da Silva.

\section{REFERENCES}

Alatoom, A. A., C. J. Cazanave, S. A. Cunningham, S. M. Ihde, and R. Patel. 2012. Identification of non-diphtheriae Corynebacterium by use of matrixassisted laser desorption ionization-time of flight mass spectrometry. J. Clin. Microbiol. 50:160-163.

Barreiro, J. R., C. R. Ferreira, G. B. Sanviso, M. Kostrzewa, T. Maier, B. Wegemann, V. Böttcher, M. N. Eberlin, and M. V. Santos. 2010. Short communication: Identification of subclinical cow mastitis pathogens in milk by matrix-assisted laser desorption time-offlight mass spectrometry. J. Dairy Sci. 93:5661-5667.

Bexiga, R., M. T. Koskinen, J. Holopainen, C. Carneiro, H. Pereira, K. A. Ellis, and C. L. Vilela. 2011. Diagnosis of intramammary infection in samples yielding negative results or minor pathogens in conventional bacterial culturing. J. Dairy Res. 78:49-55.

Costa, E. O., V. M. Carvalho, S. D. Coutinho, W. Castilho, and L. F. L. Caramori. 1985. Corynebacterium bovis e sua importância na etiologia da mastite bovina no estado de São Paulo. Pesqui. Vet. Bras. 5:65-69.

de Freitas Guimarães, F., D. B. Nóbrega, V. B. Richini-Pereira, P. M. Marson, J. C. de Figueiredo Pantoja, and H. Langoni. 2013. Enterotoxin genes in coagulase-negative and coagulase-positive staphylococci isolated from bovine milk. J. Dairy Sci. 96:28662872 .
Domingues, P. F., H. Langoni, and C. R. Padovani. 1998. Influência da mastite bovina subclínica sobre a produção de leite. Vet. Zootec. 10:99-106.

Fenselau, C., and P. A. Demirev. 2001. Characterization of intact microorganisms by MALDI mass spectrometry. Mass Spectrom. Rev. 20:157-171.

Funke, G., and K. Bernard. 2011. Coryneform gram-positive rods. Pages 413-442 in Manual of Clinical Microbiology. 10th ed. vol 1. J. Versalovic, K. Carroll, G. Funke, J. Jorgensen, M. Landry, and D. Warnock, ed. ASM Press, Washington, DC.

Gonçalves, J. L., T. Tomazi, J. R. Barreiro, D. C. Beuron, M. A. Arcari, S. H. Lee, C. M. Martins, J. P. Araújo Junior., and M. V. dos Santos. 2016. Effects of bovine subclinical mastitis caused by Corynebacterium spp. on somatic cell count, milk yield and composition by comparing contralateral quarters. Vet. J. 209:87-92.

Gonçalves, J. L., T. Tomazi, J. R. Barreiro, P. A. De Campos Braga, C. R. Ferreira, J. P. A. Junior, and M. V. Dos Santos. 2014. Identification of Corynebacterium spp. isolated from bovine intramammary infections by matrix-assisted laser desorption ionization-time of flight mass spectrometry. Vet. Microbiol. 173:147-151.

Haltia, L., T. Honkanen-Buzalski, I. Spiridonova, A. Olkonen, and V. Myllys. 2006. A study of bovine mastitis, milking procedures and management practices on 25 Estonian dairy herds. Acta Vet. Scand. 48:22.

Krieg, N. R., and J. C. Holt. 1994. Bergey's Manual of Systematic Bacteriology. 9th ed. Williams Wilkins, Baltimore, MD.

Langoni, H. 2013. Qualidade do leite: utopia sem um programasério de monitoramento da ocorrência de mastite bovina. Pesqui. Vet. Bras. 33:620-626.

Langoni, H., F. F. Guimarães, A. Salina, M. G. Ribeiro, P. V. P. Baio, J. N. Ramos, H. F. Mota, V. V. Vieira, and A. L. Mattos-Guaraldi. 2016. Molecular characterization of Corynebacterium bovis causing clinical mastitis and increasing somatic-cell count. Int. J. Adv. Vet. Sci. Technol. 5:248-255.

Lartigue, M. F., G. Héry-Arnaud, E. Haguenoer, A. Domelier, P. Schmit, N. Mee-Marquet, P. Lanotte, L. Mereghetti, M. Kostrzewa, and R. Quentin. 2009. Identification of Streptococcus agalactiae isolates from various phylogenetic lineages by matrix-assisted laser desorption ionization-time of flight mass spectrometry. J. Clin. Microbiol. 47:2284

National Mastitis Council (NMC). 1999. Laboratory Handbook on Bovine Mastitis. National Mastitis Council, Madison, WI.

Ngatia, T. A., N. E. Jensen, and B. B. Berg. 1991. Changes in the bovine udder quarters naturally infected by Corynebacterium bovis. Br. Vet. J. 147:463-468.

Pankey, J. W., R. L. Nickerson, R. L. Boddie, and J. S. Hogan. 1985. Effects of Corynebacterium bovis infection on susceptibility to major mastitis pathogens. J. Dairy Sci. 68:2684-2693.

Schalm, O. W., and D. D. Noorlander. 1957. Experiments and observations leading to development of the California Mastitis Test. J. Am. Vet. Med. Assoc. 130:199-204.

Schukken, Y. H., R. N. Gonzalez, L. L. Tikofsky, H. F. Schulte, C. G. Santisteban, F. L. Welcome, G. J. Bennett, M. J. Zurakowski, and R. N. Zadoks. 2009. CNS mastitis: Nothing to worry about? Vet. Microbiol. 134:9-14.

Tomazi, T., J. L. Gonçalves, J. R. Barreiro, P. A. De Campos Braga, L. F. P. Silva, M. N. Eberlin, and M. V. Dos Santos. 2014. Identification of coagulase-negative staphylococci from bovine intramammary infection by matrix-assisted laser desorption ionization-time of flight mass spectrometry. J. Clin. Microbiol. 52:1658-1663.

Victória, C., A. V. Silva, A. O. Elias, and H. Langoni. 2005. Corynebacterium bovis e os padrões de contagem de células somáticas no Brasil. Arq. Ciênc. Vet. Zool. UNIPAR 8:161-164.

Watts, J. L., D. E. Lowery, J. L. Teel, C. Ditto, J. S. Horng, and S. Rossbach. 2001. Phylogenetic studies on Corynebacterium bovis isolated from bovine mammary glands. J. Dairy Sci. 84:2419-2423. 